\title{
Health promotion in schools: a scoping review of systematic reviews
}

\author{
Roy Chilton \\ Mark Pearson \\ Rob Anderson* R.Anderson@exeter.ac.uk \\ Peninsula Technology Assessment Group (PenTAG) \\ Institute of Health Services Research, University of Exeter Medical School, \\ University of Exeter \\ Veysey Building, \\ Salmon Pool Lane \\ Exeter \\ EX2 4SG \\ United Kingdom \\ * Corresponding author
}

\section{Acknowledgements}

We gratefully acknowledge the valuable contributions of the wider project team to our thinking about these issues (Prof Charles Abraham, Dr Katrina Wyatt, Prof Tamsin Ford, Helen Buckley Wood), and also several peer reviewers of the original proposal to the NIHR School for Public Health Research.

This project was funded by the NIHR School for Public Health Research. The National Institute for Health Research's School for Public Health Research (NIHR SPHR) is a partnership between the Universities of Sheffield, Bristol, Cambridge, UCL; The London School for Hygiene and Tropical Medicine; The University of Exeter Medical School; the LiLaC collaboration between the Universities of Liverpool and Lancaster and 'Fuse'; The Centre for Translational Research in Public Health, a collaboration between Newcastle, Durham, Northumbria, Sunderland and Teesside Universities.

The NIHR School for Public Health Research commissioned the research following peer review, but otherwise had no involvement in the design or analysis of the research. The views expressed are those of the author(s) and not necessarily those of the NHS, the NIHR or the Department of Health

\section{Professional biographies of each author}

Roy Chilton is a health researcher and qualified health psychologist with substantial experience of working with children in schools. He recently gained his professional doctorate in health psychology.

Mark Pearson is a former nurse turned health services researcher who specialises in using systematic review methods to inform public health policy and practice. He has particular expertise in the synthesis of both qualitative and quantitative research, and 
from 2008 to 2011 led a range of systematic reviews to inform public health guidance development by the (then) National Institute for Health and Clinical Excellence.

Rob Anderson is a health services and public health researcher and evaluator with research experience in the Australian and UK health systems. From 2008 to 2011 (with Mark Pearson and others) he led a programme of work conducting evidence syntheses and economic modelling to inform public health guidance development by the National Institute for Health and Clinical Excellence. He is also an editor with the Cochrane Public Health Group (since 2012).

\section{Key words}

Health promotion, schools, systematic review, implementation

\section{Article classification}

Literature review 


\title{
Health promotion in schools: a scoping review of systematic reviews
}

\begin{abstract}
Purpose Schools are an important setting for a wide variety of activities to promote health. This systematic review aimed to map the different types of health promotion programmes and activities in schools, to estimate the amount of published evaluations of health promotion within UK schools, and to identify any provisional 'candidate programme theories' to inform a planned theory-driven systematic review.
\end{abstract}

Design Review of reviews: sixty-seven published systematic reviews of health promotion in schools were identified, from which a sub-sample of 28 systematic reviews (on 14 health topics) were retrieved for more detailed reading.

Findings Key dimensions of programme design and delivery fell mainly under the following categories: the problem and age-group of children targeted, who delivers the programme and how, and the scale and theoretical underpinning of the programme. Candidate programme theories spanned both effectiveness factors and aspects of programme implementation.

Limitations Few detailed 'candidate theories' emerged for explaining how and why health promotion can more successfully implemented in different schools.

Research implications There are five or more systematic reviews of studies of health promotion programmes in schools which target: smoking prevention; physical activity; sexual health; emotional and behavioural health and wellbeing; mental health; substance abuse; obesity/overweight. This suggests probable duplication of health problem-specific systematic reviews.

Value The findings highlight the considerable diversity of health promotion in schools, and specifies key dimensions of this diversity. They underline the need to understand better how, why, and in what circumstances health promotion can be successfully implemented in different schools and education systems. 


\section{Introduction}

For decades and in many countries schools have been seen as an important setting for policies and activities to promote health and prevent a wide variety of health problems, such as obesity/overweight, smoking, sexual health problems, unintentional injury, physical inactivity, poor diet, or mental illness/depression/bullying. Whether national or locally driven, the appeal and possible rationales for such initiatives could be that:

- they are universal (capture whole population in the relevant age-group)(World Health Organisation (WHO), 1997)

- they provide an opportunity to 'set' healthy patterns of behaviour early in a person's development which may last throughout life (Greenberg M, 2005; World Health Organisation (WHO), 1997)

- they capitalise on school children being a captive audience

- schools and schoolchildren can be used as a catalyst for changes in families and the wider community (World Health Organisation (WHO), 1997)

- in schools, some sensitive health issues (lsuch as sexual health and contraception) can be handled without parental oversight

- teachers or school peers may be more effective at delivering some types of health message or changing some health-related attitudes than others; conversely, outsiders in the classroom may work better.

Since most school-based programmes or interventions to promote health can be seen as 'complex interventions' - typically multi-component, context-sensitive, and highly dependent on the behaviours of both recipients/participants and providers - consistent and generalisable effectiveness findings by 'intervention type' are rare. The Cochrane Public Health Field recognised early (Jackson, 2005) that systematic reviews of public health interventions must address how and why they work in order to better explain variations in effectiveness (Anderson, 2008). More recently others have advocated the use of 'logic models' or other ways of enabling systematic reviews to yield better insights into how and why programmes work or fail, and why they work or fail in different circumstances (Anderson et al., 2011; Pawson, 2006). A better understanding of the effectiveness of health promotion in schools also involves understanding how the delivery of such programmes is more or less feasible and sustainable in different circumstances or when implemented differently. 
We conducted a scoping review (Grant, 2009) of published international evidence to help inform a theory-driven realist review of the implementation of health promotion in schools. The aim of the realist review will be to explain how, why and in what circumstances schools can be feasible and sustainable settings for implementing health promotion programmes in the UK (see review protocol registered on PROSPERO (Pearson et al., 2012a; Pawson, 2006; Pearson et al., 2012b). Unlike conventional reviews of the effectiveness of interventions, this planned realist review therefore aimed to 'hold constant' not the type of intervention but the nature of the context. Essentially, our planned review aimed to begin to tease out what it is about schools - the way they are staffed and governed, the way they are linked to communities, the way they are incentivised about academic attainment relative to other goals, the way the curriculum is enforced, the way their days are timetabled, the way they are physically built and so on, that makes them a feasible (or unfeasible) setting for promoting children's health and wellbeing. To do this well we needed to be (a) familiar with the potential dimensions of variation of the design and delivery of the programmes themselves, and (b) be sure there were enough primary research studies in the school and education system(s) of interest (i.e. United Kingdom).

\section{Aims \& Objectives:}

This review of previously published systematic reviews aimed:

1. To map the range of different types of health promotion programmes and activities in schools (including some elaboration of the dimensions along which different programmes vary)

2. To assess the focus and amount of published evaluations of health promotion within UK schools

3. To identify any provisional 'candidate programme theories' - that is, ideas regarding how and why schools are thought to be feasible and sustainable settings for health promotion; or, conversely, to identify insights/theories about why in certain circumstances, with certain types of schools or in relation to particular types of health problem, they are not).

The third aim was opportunistic, given that this review of reviews was preparatory research for a planned realist review that followed, and even though we were not 
particularly optimistic about the conceptual richness or explanatory focus of systematic reviews of randomised trials as a source of programme theories.

\section{Methods}

We searched two databases of systematic reviews: the Cochrane Database of Systematic Reviews (CDSR) and the Database of Promoting Health Effectiveness Reviews (DoPHER). The CDSR provides high-quality, independent evidence of the effectiveness of health interventions, while DoPHER is a specialised register of health promotion reviews which provides coverage of systematic and non-systematic reviews of effectiveness in health promotion and public health worldwide. Since this review was primarily to gauge the diversity of such programmes, and also to make a preliminary assessment of the amount of published evidence from UK school settings, we believed that searching only these two databases would provide a reliable and sufficiently complete pool of studies to answer our review questions.

The DoPHER database (April, 2012) was searched using free-text terms "school" (464 records) and "systematic review" (766 records). These numbers were reduced by combining "school" AND "systematic review" to give 127 records (after removal of 1 duplicate). Sixty-six of these were retained for full-text screening because their titles included the word "school". Of the remaining 61 records, 27 abstracts were printed off for further screening (34 studies were dismissed in terms of relevance to this study). The CDSR database (April, 2012) was searched using "school" in the title, abstract or keyword, this located 120 records, 7 of which met our inclusion criteria (see below). Table 1 provides a summary of the identified health topic areas and number of retrieved systematic reviews for each topic (a list of all identified systematic reviews is available upon request).

Inclusion criteria:

- Health promotion was defined as "the process of enabling people to increase control over their health and its determinants, and thereby improve their health" (Bangkok Charter, 2005) through trying to change the attitudes, knowledge or behaviours people (schoolchildren)

- All school settings (e.g. primary, secondary, after-school clubs). 
- The primary site where the health promotion programme was delivered had to be within the school (either classrooms, other school buildings or within the school outdoor areas).

- $\quad$ Any age group up to 19 years of age.

- Systematic reviews (i.e. reviews with explicit aims and explicit methods for identifying (searching), selecting and appraising included studies)

Exclusion criteria:

- Non-systematic reviews (e.g. critical reviews, literature searches).

- Where $<50 \%$ (approximately) of the included studies were school-based. *** INSERT TABLE 1 ABOUT HERE ***

Following this initial search, additional exclusion criteria were discussed and applied to improve the relevance of identified reviews. These criteria considered the nature of school systems and its appropriateness to UK schools, and also the severity and range of health problems addressed. Optional schooling for those of pre-school age such as 'pre-school' and 'day care' were also excluded on the basis that they were not compulsory schooling.

Further exclusion criteria:

- Single country systematic reviews (unless UK).

- Any systematic reviews of school-based health promotion consisting of studies only from developing countries.

- Where the focus was not directly related to change to attitudes, knowledge or behaviour of children (i.e. growth monitoring within schools would be excluded).

- Where the specific focus was on either pre-school or day care settings.

For each health topic area, the following criteria were then used make a purposive sample of two full-text systematic reviews.

- $\quad$ systematic reviews published within the last 5 years, OR (if one or none):

- the most recent from each subject area.

- the most recent relevant Cochrane systematic reviews where possible. 
Given the large number of systematic reviews in some health topic areas, this purposive sampling approach seemed appropriate to the gain a representative spread of studies from different public health problem areas (for addressing aims 1 and 2).

Included systematic reviews were read in detail, to extract the following information relevant to our review questions:

- the key features or dimensions of variation of school-based health promotion programmes;

- the total number of included primary effectiveness studies in each health/intervention topic area (after removing any duplicates included in both reviews);

- the country in which each primary study and programme was based; any stated explanatory factors or theoretical mechanisms related to the successful introduction, implementation or sustainability of health promotion in schools.

Given the descriptive (as opposed to evaluative) and scoping aims of the review, we did not formally assess the quality of the included systematic reviews. The only marker of review quality of interest was the extent to which each review sought to explain differences in effectiveness or implementation success amongst the included primary studies.

\section{Results}

We retrieved 28 systematic reviews in full-text (two for each of 14 health topic areas) (see Appendix). Information from these studies was used to construct a diagram summarising the key dimensions of variation of school-based health promotion programmes (Figure 1), gauge the quantity of UK-based primary studies across different health problems (Figure 2), and derive some initial candidate theories of successful programme implementation in schools (Table 2).

\section{Dimensions of school based health promotion programmes}

Figure 1 highlights the diversity of factors inherent in delivering health promotion programmes within school settings, both in the UK and internationally. In addition to the more obvious variations between programmes, such as in the specific health 
problems targeted and the age range of schoolchildren involved, there were a number of aspects of how programmes are delivered which might impact on their feasibility and sustainability in different schools. These included: the mode of delivery and interaction format; the duration of the whole programme and the number and length of sessions within it; the theoretical basis (such as social learning, or other psychological behaviour change approaches); and the specific targeted behaviours or skills (e.g. problem-solving, goal-setting or reducing negative thinking). The variety of possible methods for delivering programmes was wide.

The scale of delivery could be either whole school, whole year-group or classroombased. Likewise the complexity of programmes varied from single component to multi-component interventions comprising behaviour change of staff and children and changes to the school environment and school policies. Given that many of these dimensions might be expected to impinge on the effectiveness of programmes, it is unsurprising that systematic reviews bounded by traditional 'PICO' criteria produce such mixed findings (i.e. reviews focussed on specific Populations, Interventions, Comparators and Outcomes).

In the sampled systematic reviews, there was limited consideration regarding the stated theoretical or conceptual underpinnings of the evaluated health promotion programmes.

\section{*** INSERT FIGURE 1 ABOUT HERE ***}

\section{Amount of UK-based primary studies}

Within the sampled systematic reviews, analysis of the number of primary studies identified 65 (8\%) that were UK-based (Figure 2). Within the individual topic areas, nutrition (23) and diet (8) contained the greatest number of UK-based studies relative to evaluated programmes in other countries, and together these accounted for almost half of the UK-based studies. Fifty-four of the 65 UK primary studies related to promoting improved nutrition, diet, mental health, sexual health or reducing smoking. This was in contrast to evaluated programmes targeting alcohol abuse, physical activity and miscellaneous (e.g. dog bite injury prevention) which contained no UKbased studies. Compared with the international literature, there were also relatively 
few published effectiveness evaluations of UK school-based programmes aimed at improving general physical health (one study), preventing sexual abuse (one study) or preventing substance abuse (only one UK study in the two included systematic reviews).

\section{Provisional theories about the implementation of health promotion in schools}

This review of reviews also helped to identify some provisional candidate theories for explaining implementation success. This allowed a better appreciation of how candidate theories relating to the effectiveness of programmes as opposed to the successful implementation of programmes may be both distinct and interlinked. It also helped us to clarify and focus on features of implementation which emphasised feasibility (i.e. 'real world' practical implementation issues) and sustainability (ability to embed such programmes into routine school life and resource constraints).

Table 2 and 3 about here.

Table 2 summarises some of the implementation factors related to policy, teaching time and practices, age and developmental characteristics of students, as well as how programmes impacted upon the curriculum. Table 3 shows more detailed information extracted from the each of included reviews where they stated or implied particular causal mechanisms relating to programme effectiveness, feasibility or sustainability. We have highlighted (in bold text) those explanatory insights which seemed most relevant to the feasibility and sustainability of health promotion activities in schools. Overall, however, more attention and space in the reviews was devoted to factors which helped explain variations in effectiveness, without separately describing how variations in completeness of quality of programme implementation might underlie variations in effectiveness.

\section{Discussion}

Main findings of this study 
The scoping review of systematic reviews has been able to describe the considerable diversity of school-based health promotion programmes and confirm that UK-based programs have been evaluated in a variety of health topic areas. The programmes vary in terms of the problem and age-group of children targeted, who delivers the programme and how, and the scale and theoretical underpinning of the programme. In terms of their associated settings, they have to fit into or adapt to both the national school systems and the variety of local settings (school, community, primary care, internet) in which their activities are intended to occur.

Knowing these broad dimensions of this diversity, and more detailed and recurrent aspects of programme design and delivery, can be a basis for better explaining variations in effectiveness and cost-effectiveness. Ideally, some of these dimensions should be used as additional and standard data extraction fields in future systematic reviews health promotion in schools. In this way, overviews or reviews of reviews might be able to draw conclusions about what features of programme design and delivery, or what features of school engagement or adaptability, are most associated with programme success.

The review has also identified a number of provisional theories that provide insight into the nature of implementation of health promotion within school settings. They are provisional in the sense that they may be directly supported by the primary research evidence included in the included systematic reviews, and for example may simply be the speculative explanations offered by review authors for between-trial heterogeneity. Nevertheless, they may be a useful start either in terms of offering inherently plausible explanations or providing a collection of initial theories that can be compared with those emerging from richer or less synthesised and summarised sources.

\section{What is already known on this topic}

Evidence for the effectiveness of different school-based health promotion interventions is difficult to generalise because of extensive heterogeneity in measured outcomes, methods, intervention types, target populations and settings (Brown, 2009; Lister-Sharp, 1999). Also, while there are many systematic reviews of the evidence of school-based interventions, they tend to be highly problem- or intervention type- 
specific. They therefore miss potential school and school system-specific insights about the nature of implementation of such programmes across different health problems. This review of reviews was the first step to inform a theory-driven review to understand better how and when UK schools can be a feasible and sustainable setting for promoting health (Pearson et al, 2012).

\section{What this study adds}

This scoping review has highlighted the wide range of factors inherent in both the design and introduction and the delivery and longer term sustainability of health promotion programmes in schools. Many of these programme characteristics, from the underlying theory, mode of delivery and number and duration of sessions, would be expected to be causally related to intended outcomes. From these, it should be possible to define a standard collection of programme characteristics which could be defined for any health promotion programme delivered within schools (or other organisations, such as workplaces). Such a minimum descriptive dataset is essential for enhancing the generalisability of individual pieces of primary research, as well as important in allowing systematic reviews of effectiveness studies to more fully take account of variation in how programmes have been implemented (Waters et al., 2011). It would parallel useful developments by the Cochrane Effective Practice and Organisation of Care (EPOC) group, who have developed a standard Data Collection Checklist for describing and assessing the detailed content and settings of interventions to improve adherence to evidence-based practice (Cochrane Effective Practice and Organisation of Care Review Group (EPOC), 2002).

This review also showed that while the range of health topics promoted and evaluated in the UK appears to be broadly similar to those evaluated in other countries, most published evaluations of programmes in UK schools focused on only four health topics: diet/nutrition, smoking, mental health and sexual health.

\section{Limitations of this study}

While this scoping exercise was informative in identifying various dimensions of the design and implementation of health promotion programs within schools, it was less useful for retrieving 'candidate theories' regarding how, why and in what circumstances health promotion is more successfully implemented in schools. To 
some extent this was expected because, compared with studies reporting primary research, within systematic reviews there is often more limited space for detailed explanations of how and why programmes are thought to be effective.

By surveying studies in systematic reviews, the revealed mix of studies and programme topics from the UK will partly represent areas where more rigorous evaluation study designs have been used. The characteristics of programmes in published studies included in systematic reviews may not closely reflect the actual prevalence of health promotion programmes in schools, as some types of health promotion in schools may be more well-established and accepted - and therefore less often or less rigorously evaluated.

\section{Conclusion}

Our review reveals the extreme diversity of delivery methods and content of delivering health promotion programmes in schools, and suggests some broad dimensions and some school- and programme-specific features for better capturing this diversity. It has also shown that at the level of intervention types and targeted problems, there are already very many systematic reviews of such programmes - we found 67 . The review has also suggested some initial programme theories specifically relating to the implementation of health promotion in school settings. However, it has also highlighted the limitations of using systematic reviews, especially systematic reviews of effectiveness studies, as a source of underlying programme theories. Despite encouragement for using 'logic models' and more programme theory in systematic reviews (Anderson, 2011; Jackson, 2005), many of these reviews devoted no or little space to explaining how programme components and contextual features were thought to combine to create their intended outcomes. 
Table 1. Identified published systematic reviews by topic area identified

\begin{tabular}{|l|l|}
\hline Topic Area & Retrieved Systematic Reviews \\
\hline Obesity/weight & 9 \\
\hline Substance abuse & 8 \\
\hline Mental health & 7 \\
\hline Emotional and behavioural & 7 \\
\hline Sexual health & 6 \\
\hline Physical activity & 5 \\
\hline Smoking & 5 \\
\hline Health promotion (general) & 4 \\
\hline Physical health & 4 \\
\hline Diet or Nutrition & 4 \\
\hline Alcohol & 3 \\
\hline Sexual abuse & 2 \\
\hline Miscellaneous: & 3 \\
\hline Total & 67 \\
\hline
\end{tabular}


Table 2. A selection of candidate theories regarding the successful implementation of health promotion programmes in schools

\begin{tabular}{|c|c|c|}
\hline $\begin{array}{l}\text { Candidate theories - based on health } \\
\text { promotion programme implementation }\end{array}$ & As expressed in review & Area of health promotion \\
\hline $\begin{array}{l}\text { Successful implementation is dependent on the } \\
\text { commitment of members of staff within the } \\
\text { school }\end{array}$ & $\begin{array}{l}\text { "Many studies described the challenges inherent to implementing } \\
\text { programmes in school, highlighting the importance of commitment } \\
\text { from head teachers and all teaching staff" (Blank, 2009, p. 74) }\end{array}$ & Emotional and behavioural \\
\hline $\begin{array}{l}\text { Health promotion is more sustainable when those } \\
\text { receiving the intervention have continuity and } \\
\text { familiarity with the programme }\end{array}$ & $\begin{array}{l}\text { "The intervention should likely be implemented multiple times within } \\
\text { and across the school years" (Schachter, 2008, p. 7) } \\
\text { "[the review authors] propose a curriculum, whose implementations } \\
\text { reinforce and build upon prior ones" (Schachter, 2008, p. 7) }\end{array}$ & Mental health \\
\hline $\begin{array}{l}\text { Those delivering health promotion programmes } \\
\text { should have familiarity with its recipients }\end{array}$ & $\begin{array}{l}\text { "implementers, who include those experiencing mental health } \\
\text { difficulties should likely be those with whom the children or youth are } \\
\text { most likely to identify (e.g., those most similar to themselves). Yet, } \\
\text { [also] actively involving their teachers, other school staff, the school } \\
\text { administration and parents could maximise the likelihood of making a } \\
\text { sustainable difference" (Schachter, 2008, p. 7-8) }\end{array}$ & Mental health \\
\hline $\begin{array}{l}\text { Implementation can be improved by involving } \\
\text { the student in order to improve on the relevance } \\
\text { and developmental appropriateness of the } \\
\text { programme }\end{array}$ & $\begin{array}{l}\text { "child and adolescent involvement in creating refining and test piloting } \\
\text { the curriculum is likely essential to maximise the relevance and } \\
\text { developmental appropriateness of its components and the timing of } \\
\text { their implementations" (Schachter, 2008, p. 8) } \\
\text { "Developmentally-appropriate discussions could be scheduled } \\
\text { strategically over the years, which successively focus attention on } \\
\text { issues" (Schachter, 2008, p. 9) } \\
\text { "Programs ought to consider and manage the developmental } \\
\text { appropriateness of content (at the level of specific concepts) and } \\
\text { delivery to different ages, developmental stages, and cultural and } \\
\text { familial acceptability" (Topping, 2009, p. 455-456) }\end{array}$ & Mental health \\
\hline $\begin{array}{l}\text { Health promotion needs to be integrated into the } \\
\text { school environment to facilitate and support the } \\
\text { continuation of positive health behaviours }\end{array}$ & $\begin{array}{l}\text { "not realistic to expect that students will continue adopt healthy diet } \\
\text { behaviour at school if the school environment does not support these } \\
\text { behaviours continually" (Jaime, 2009, p. 52) }\end{array}$ & Obesity weight \\
\hline
\end{tabular}

Table 3. Key explanatory insights as possible basis for forming candidate theories, by source 


\begin{tabular}{|c|c|c|}
\hline Author (year) & Health area & Explanatory insights \\
\hline Foxcroft (2011) & Alcohol & $\begin{array}{l}\text { - Cultural norms around alcohol impact strongly on effectiveness of interventions } \\
\text { - Generic psychosocial/ developmental prevention programmes may have an impact far beyond just e.g. alcohol } \\
\text { use }\end{array}$ \\
\hline Wood (2006) & Alcohol & "The most common combination of interventions involved schools, parents and resources" \\
\hline $\begin{array}{l}\text { Delgado- } \\
\text { Noguera (2011) }\end{array}$ & Diet & $\begin{array}{l}\text { "Based on our results, computer-based interventions should be promoted given that most schools have } \\
\text { computers and these interventions do not imply such as big expenditure as would be multicomponent } \\
\text { interventions or free provision of fruits" (p8) }\end{array}$ \\
\hline De Sa (2008) & Diet & $\begin{array}{l}\text { - "results are limited to developed countries" } \\
\text { - "Much of the current focus for obesity policy is on younger children with the perception that diets of younger } \\
\text { children are easier to change. This review shows that increasing fruit \& vegetable intake is possible across a } \\
\text { wide age range.......particularly important in teenagers" } \\
\text { - "school fruit \& vegetable schemes.. added benefit of reducing health and social inequalities" (i.e. } \\
\text { free/subsidised schemes) } \\
\text { - "The evidence to date suggests that <1 year free fruit \& vegetables is not sufficient for long-term dietary } \\
\text { change..... any EU funded programme should not only provide fruit \& vegetables to children free of charge, } \\
\text { but this should run over several years and allow further evaluation of long-term effectiveness" } \\
\text { - "not possible to identify the most effective components" } \\
\text { - "policy makers...need to understand that multiple changes in social, economic and physical aspects of } \\
\text { children's environments.....schools are only one aspect of this" }\end{array}$ \\
\hline Blank (2009) & $\begin{array}{l}\text { Emotional and } \\
\text { behavioural }\end{array}$ & $\begin{array}{l}\text { Barriers to - and facilitators of effective implementation: } \\
\text { - "Many studies described the challenges inherent to implementing programmes in school, highlighting the } \\
\text { importance of commitment from head teachers and all teaching staff" } \\
\text { The authors refer to research highlighting "the perceived extra burden from teaching the new curriculum, and } \\
\text { conflict with their teaching style" (Orpinas et al., 2000) } \\
\text { - "entire staff needed to put energy and resources into the programme" (Farrell et al., 2003) }\end{array}$ \\
\hline Joronen (2008) & $\begin{array}{l}\text { Health promotion } \\
\text { (general) }\end{array}$ & $\begin{array}{l}\text { - Authors refer to previous research (Cuijpers, 2002) which utilised interactive delivery methods and the social } \\
\text { influence model, focussing on norms, commitment and intentions. } \\
\text { - Authors describe the use of peer leaders to increase the effects of the programmes. } \\
\text { - "the most appropriate time for intervention implementation may be earlier in adolescence, before the onset of } \\
\text { risky behaviours" }\end{array}$ \\
\hline $\begin{array}{l}\text { Kavanagh } \\
(2009)\end{array}$ & Mental health & $\begin{array}{l}\text { - "suggests that CBT type interventions can be delivered effectively in naturalistic settings" } \\
\text { - "this is a positive finding from a public health perspective" } \\
\text { - "interventions ... delivered during the school day and provided by existing school staff appeared to have a } \\
\text { greater impact than those provided by non-school staff, such as researchers and psychologists" } \\
\text { - } 10 \text { or more sessions were more effective than shorter ones "It may be that much longer interventions are } \\
\text { required to teach young people the cognitive skills needed to protect themselves from depression" }\end{array}$ \\
\hline
\end{tabular}




\begin{tabular}{|c|c|c|}
\hline & & $\begin{array}{l}\text { - Possible trend (not significant) towards less effectiveness within SES populations, authors note "exposure to } \\
\text { higher levels of stressful conditions and adversity that young people in lower SES families may face" } \\
\text { - "this analysis illustrates the point that well intended interventions may worsen rather than reduce inequalities" } \\
\text { - Universal interventions questioned in terms of effectiveness by the authors (also have support from another } \\
\text { review). They mention "indicated" interventions } \\
\text { - "need to understand how the content, intensity, duration and delivery format of interventions may contribute to } \\
\text { differential capacity and take these factors into account in when designing future CBT based interventions }\end{array}$ \\
\hline $\begin{array}{l}\text { Schachter } \\
(2008)\end{array}$ & Mental health & $\begin{array}{l}\text { Authors cannot recommend any single school-based intervention or intervention type } \\
\text { - "Interventions should likely involve experiential activities, .......engage students' feelings and behaviour, not } \\
\text { just cognition-based points of view" } \\
\text { - "implemented multiple times within and across the school years" } \\
\text { - "propose a curriculum, whose implementations reinforce and build upon prior ones" } \\
\text { - "implementers...should likely be those with whom the children or youth are most likely to identify....yet, } \\
\text { actively involve their teachers, other school staff, the school administration and parents could maximise the } \\
\text { likelihood of making a sustainable difference" } \\
\text { - "child and adolescent involvement in creating refining and test piloting the curriculum is likely essential to } \\
\text { maximise the relevance and developmental appropriateness of its components and the timing of their } \\
\text { implementations" } \\
\text { - "contact-based interventions which reflect an experiential approach" } \\
\text { - "we hypothesize that empathy is the mechanism by which contact can produce substantive, behavioural } \\
\text { change" (more detail described by authors) } \\
\text { - "Developmentally-appropriate discussions could be scheduled strategically over the years, which successively } \\
\text { focus attention on issues" } \\
\text { - "Engaging their conceptual frameworks would depend upon children's cognitive and affective readiness" }\end{array}$ \\
\hline $\begin{array}{l}\text { Kristjansson } \\
(2007)\end{array}$ & Nutrition & $\begin{array}{l}\text { - Substitution - "In poor families, to spread limited, the home diet may be reduced for children who are receiving } \\
\text { food at school" } \\
\text { - "provision of school breakfast makes children feel valued and increases the general attention given to them" } \\
\text { - "school feeding should be combined with other interventions that aim to improve country educational } \\
\text { attainment" }\end{array}$ \\
\hline $\begin{array}{l}\text { Van } \\
\text { Cauwenberghe } \\
(2010)\end{array}$ & Nutrition & $\begin{array}{l}\text { - "In children there is strong evidence that multicomponent interventions that combine improved availability of } \\
\text { fruit and vegetables with a nutrition education curriculum delivered by the teacher and at least some parent } \\
\text { involvement can alter intake of fruit and vegetables" } \\
\text { - "limited evidence of effect size was found for nutrition education only programmes delivered by teachers using } \\
\text { practical activities such as taste testing, cooking classes etc." }\end{array}$ \\
\hline Jaime (2009) & Obesity/weight & $\begin{array}{l}\text { - in reference to food regulation "students may compensate for the lack of access to "banned" foods by buying } \\
\text { other popular processed foods, in this case ice-cream sales increased" } \\
\text { - Length of intervention "not realistic to expect that students will continue adopt healthy diet behaviour at school }\end{array}$ \\
\hline
\end{tabular}




\begin{tabular}{|c|c|c|}
\hline & & $\begin{array}{l}\text { if the school environment does not support these behaviours continually" } \\
\text { - Industry / government mentioned }\end{array}$ \\
\hline Stevens (2010) & $\begin{array}{l}\text { Obesity/weight } \\
\text { (in Ethnic } \\
\text { minority) }\end{array}$ & $\begin{array}{l}\text { - Suggests "addressing specific factors that influence this age group...... behavioural strategies that increase self- } \\
\text { esteem and motivation, and target poor health practices... exposure to television and other sedentary } \\
\text { behaviours...neighbourhood safety...parental inclusion in intervention programs" } \\
\text { - Describes community-based nursing for ethnic minorities, understanding cultural norms i.e. eating traditions, } \\
\text { safe recreational areas, access to grocery stores }\end{array}$ \\
\hline Kriemler (2011) & Physical activity & $\begin{array}{l}\text { - "a multicomponent mandatory programme with the involvement of specialists and supported by the families } \\
\text { seems to be effective in increasing overall physical activity in children }\end{array}$ \\
\hline Dobbins (2009) & Physical activity & $\begin{array}{l}\text { } P \text { Physical Activity by: } \\
\text {-improving knowledge \& providing a conducive environment } \\
\text { - fostering positive attitudes } \\
\text { - To act as role models } \\
\text { - parental involvement } \\
\text { - lobbying local and provincial policy makers to increase resources } \\
\text { - Works differently in boys/girls: } \\
\text { Boys - where promotion of Physical Activity reinforces individuality, fosters identity and promotes activity at } \\
\text { an earlier age } \\
\text { Girls - group activities that enable affiliation amongst peers/family }\end{array}$ \\
\hline D'Onise (2010) & Physical health & $\begin{array}{l}\text { - "few studies were explicit about the proposed mechanisms for the intervention bring about beneficial health } \\
\text { outcomes" } \\
\text { - "the true extent of potential benefit from ECD interventions on health outcomes in childhood has not been } \\
\text { adequately characterised... This has limited the ability to form an overarching conclusion about the effect of } \\
\text { preschool programs on child health outcomes" } \\
\text { - No evidence of benefit from inclusion of health services in the intervention components" } \\
\text { - Intervention that have both direct educational services to children and indirect services through parents are } \\
\text { likely to have more beneficial outcomes than those interventions that include direct services to children alone" }\end{array}$ \\
\hline Topping (2009) & Sexual abuse & $\begin{array}{l}\text { - "Effective school-based abuse prevention programs need to: have evaluation of effectiveness built in; } \\
\text { incorporate modelling discussion, and skills rehearsal; be at least four to five sessions long; have the capacity } \\
\text { to be delivered by a range of personnel; involve active parental input" } \\
\text { - "Programs ought to consider and manage the developmental appropriateness of content (at the level of specific } \\
\text { concepts) and delivery to different ages, developmental stages, and cultural and familial acceptability" }\end{array}$ \\
\hline Blank (2010) & Sexual health & $\begin{array}{l}\text { Due to the U.S focus "differences in terms of school-based culture, policy and context may be much more } \\
\text { varied between countries and therefore caution is required when applying US evidence elsewhere" }\end{array}$ \\
\hline Owen (2010) & Sexual health & $\begin{array}{l}\text { - "anonymity and lack of stigma may encourage attendance at a UK school-based clinic" (Chapter } 6 \text { - } \\
\text { effectiveness) } \\
\text { - Chapter } 7 \text { (varied - qualitative) }\end{array}$ \\
\hline
\end{tabular}




\begin{tabular}{|l|l|l|}
\hline & & $\begin{array}{l}\text { - Chapter 8 "access to condoms was therefore improved when the barrier of visibility was addressed" (more } \\
\text { private locations for distribution) }\end{array}$ \\
\hline Thomas (2008) & Smoking & $\begin{array}{l}\text { - Multi-modal interventions (e.g. social influence models combined with generic social competence training } \\
\text { and/or community interventions) may be more effective, but require substantial investment in teacher training } \\
\text { and take up large chunks of classroom time }\end{array}$ \\
\hline Uthman (2009) & Smoking & $\begin{array}{l}\text { - Barriers and facilitators - poor student attendance. } \\
\text { - "it is generally recognised that an intervention needs to be tailored to suit the age of its target population" } \\
\text { " "weak evidence indicating that school-based interventions starting soon after entry into primary schools may be } \\
\text { effective in reducing the uptake of smoking up to the age of 14, and strong evidence that booster sessions } \\
\text { enhance effectiveness of main programmes" }\end{array}$ \\
\hline $\begin{array}{l}\text { Faggiano } \\
\text { 2008) }\end{array}$ & Substance abuse & $\begin{array}{l}\text { - Programmes that address life skills (individual risk and protective factors) are most effective } \\
\text { - cf. Cochrane alcohol SR - suggests similar pathways for alcohol, tobacco and drug use } \\
\text { - Role of additional components (peer influence, booster sessions, involvement of parents) not known } \\
\text { (inadequately evaluated) }\end{array}$ \\
\hline $\begin{array}{l}\text { Lemstra (2010) } \\
\text { Bourdeaudhuij } \\
(2010)\end{array}$ & Substance abuse & $\begin{array}{l}\text { " "multi-factorial and combine knowledge with refusal skills, self-management skills, and social skills have long } \\
\text { term effectiveness in comparison to programs that focus on knowledge alone" }\end{array}$ \\
\hline
\end{tabular}

See Appendix for full reference citations 


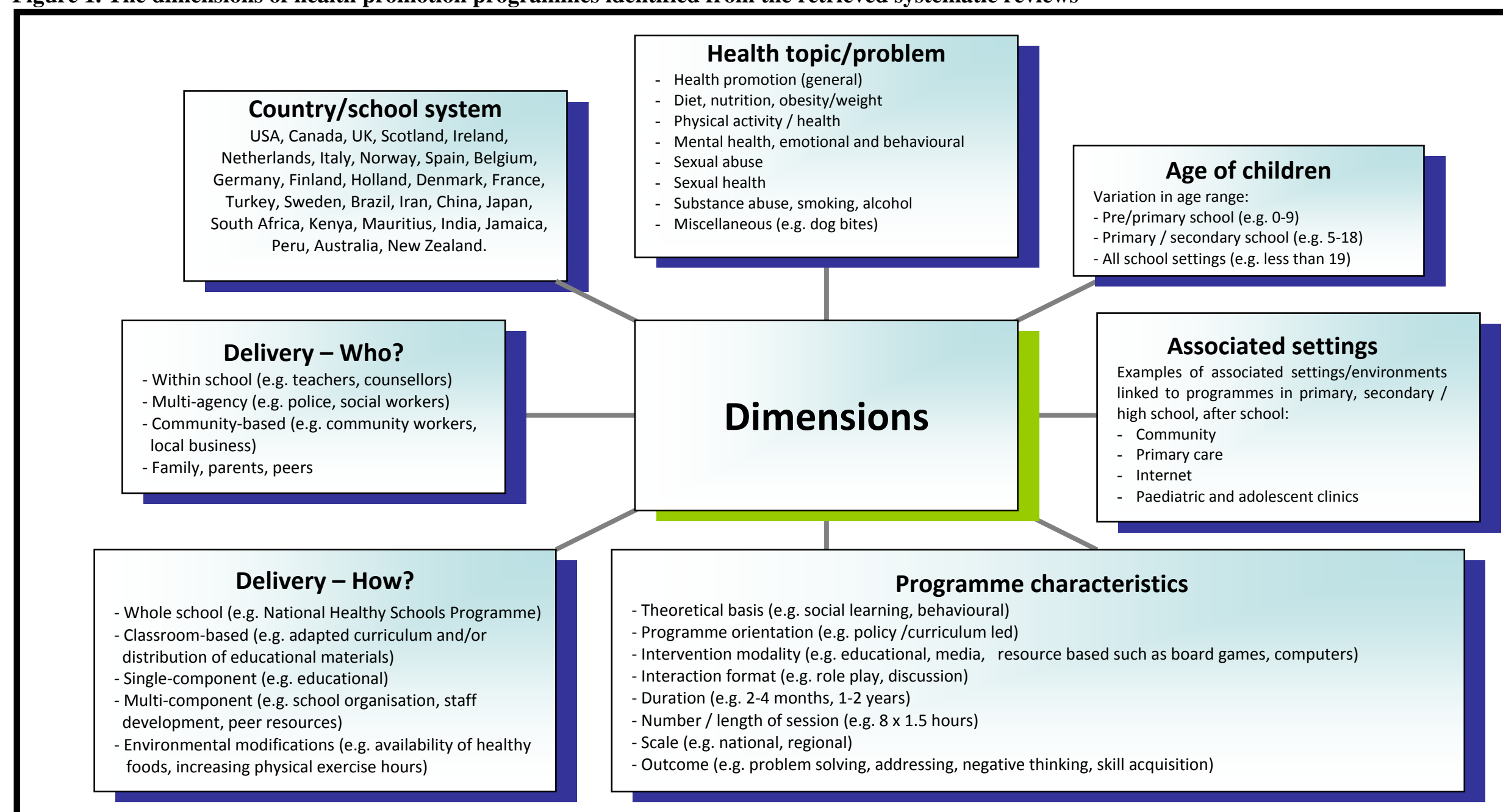


Figure 2. Health promotion topic coverage within sampled systematic reviews by country of primary studies

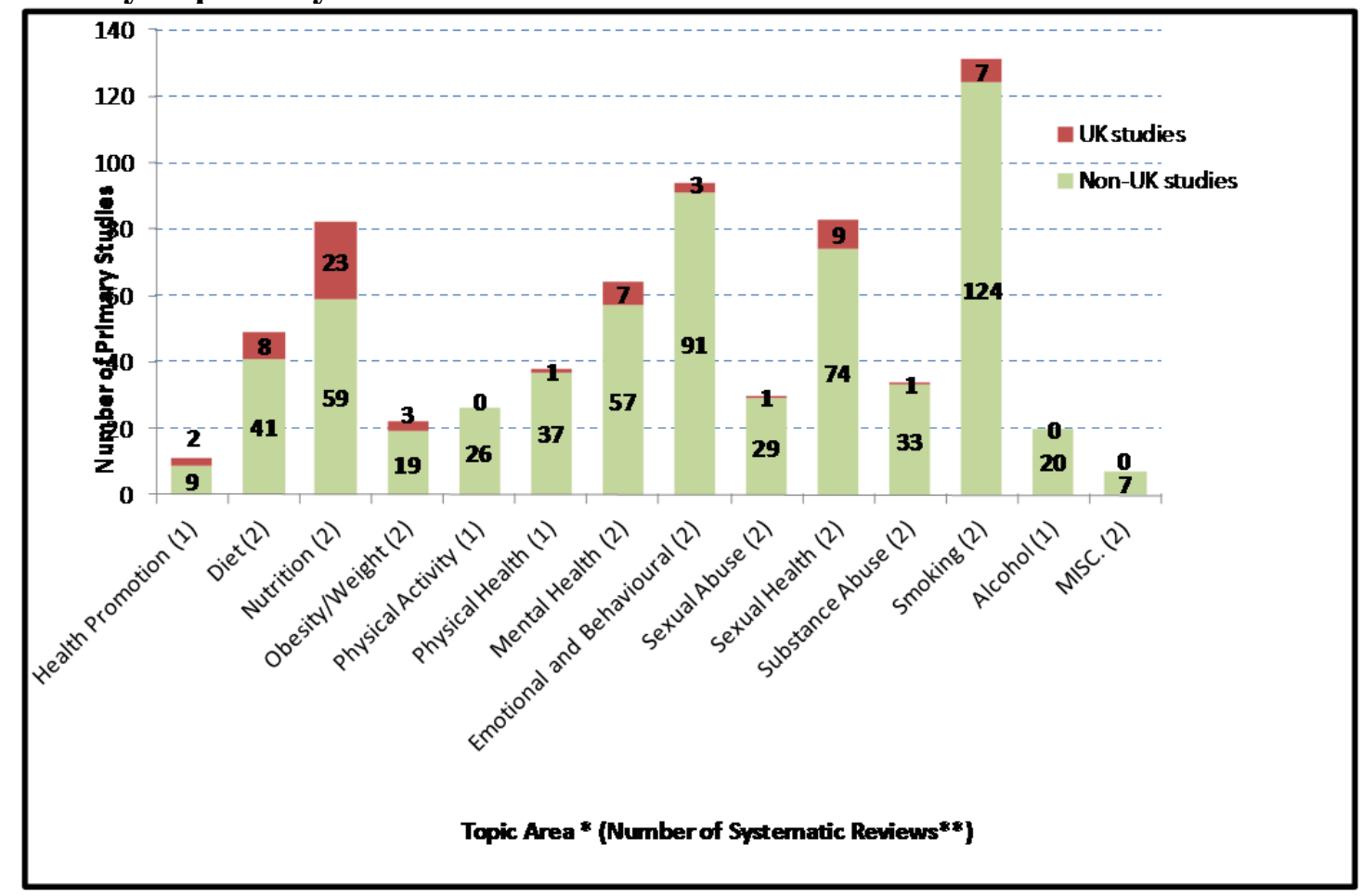

* Duplicates within each topic area removed

** Number of systematic reviews that contained information on the country of included primary studies 


\section{References}

Anderson, L. M., Petticrew, M., Rehfuess, E., Armstrong, R., Ueffing, E., Baker, P., Francis, D., Tugwell, P. (2011), "Using logic models to capture complexity in systematic reviews". Research Synthesis Methods, Vol 2 No.1, pp. 33-42.

Anderson, R. (2008), "New MRC guidance on evaluating complex intervention: clarifying what interventions work by researching how and why they are effective". British Medical Journal, Vol. 337, p. a1937.

Blank, L., Baxter, S., Goyder, L., Guillaume, L., Wilkinson, A., Hummel, S., \& Chilcott, J. (2009), Systematic Review of the Effectiveness of Universal Interventions Which Aim to Promote Emotional and Social Wellbeing in Secondary Schools. University of Sheffield: Sheffield: School of Health and Related Research (ScHARR), Sheffield.

Brown, T., Summerbell, C. (2009), "Systematic review of school-based interventions that focus on changing dietary intake and physical activity levels to prevent childhood obesity: an update to the obesity guidance produced by the National Institute for Health and Clinical Excellence". Obesity Reviews, Vol. 10 No. 1, pp. 110-141.

Cochrane Effective Practice and Organisation of Care Review Group (EPOC) (2002). Data Collection Checklist. Ottawa, Canada, Cochrane EPOC Group, University of Ottawa.

Grant M.J. and Booth, A. (2009). "A typology of reviews: an analysis of 14 review types and associated methodologies". Health Information and Libraries Journal, Vol. 26, pp. 91-108.

Greenberg M, Domitrovich C., Gaczyk P, Zins J. (2005), The Study of Implementation in School-based Preventive Interventions: Theory, Research and Practice (Volume 3). Center for Mental Health Services, the Substance Abuse and Mental Health Services Administration, U.S. Department of Health and Human Services (DHHS), Rockville MD.

Jackson, N., Waters, E., for the Guildelines for Systematic Reviews in Health Promotion and Public Health Taskforce (2005), "Criteria for the systematic 
review of health promotion and public health interventions". Health Promotion International, Vol. 20 No. 4, pp. 367-374.

Jaime, P. C., and Lock, K. (2009), "Do school based food and nutrition policies improve diet and reduce obesity?". Preventive Medicine, Vol. 48, pp. 45-53.

Lister-Sharp, D., Chapman, S., Stewart-Brown, S., Sowden, A. (1999), "Health promoting schools and health promotion in schools: two systematic reviews". Health Technology Assessment, Vol. 3 No. 22.

Pawson, R. (2006), Evidence-based Policy: a Realist Perspective. SAGE Publishing Ltd., London.

Pearson M, Chilton R, Woods HB, Wyatt K, Ford T, Abraham C, Anderson, R (2012a). Implementing health promotion in schools: a realist systematic review of research and experience in the UK. PROSPERO 2012:CRD42012002640 Available from:

http://www.crd.york.ac.uk/PROSPERO/display_record.asp?ID=CRD4201200 $\underline{2640}$, accessed 19 January 2015

Pearson, M., Chilton, R., Woods, H.B., Wyatt, K., Ford, T., Abraham, C., Anderson, R. (2012b), "Implementing health promotion in schools: protocol for a realist systematic review of research and experience in the United Kingdom (UK)". Systematic Reviews, Vol. 1 No. 48.

Schachter, H. M., Girardi, A., Ly, M., Lacroix, D., Lumb, A. B., van Berkom, J. \& Gill, R. (2008), "Effects of school-based interventions on mental health stigmatization: a systematic review". Child and Adolescent Psychiatry and Mental Health, Vol. 2 No. 18.

Topping, K. J., and Barron, I. G. . (2009), "School-based child sexual abuse prevention programs: a review of effectiveness". Review of Educational Research, Vol. 79 No. 1, pp. 431-463.

Waters, E., Hall, B. J., Armstrong, R., Doyle, J., Pettman, T. L., \& de SilvaSanigorski, A. (2011), "Essential components of public health evidence reviews: capturing intervention complexity, implementation, economics and equity". Journal of Public Health, Vol. 33 No.3, pp. 462-465. 
World Health Organisation (WHO). (1997), Promoting Health Through Schools: Report of a WHO Expert Committee on Comprehensive School Health Education and Promotion. WHO, Geneva. 
Appendix. The 28 reviews chosen for more detailed assessment

\begin{tabular}{|c|c|}
\hline $\begin{array}{l}\text { Targeted } \\
\text { health topic }\end{array}$ & Review reference \\
\hline Alcohol & $\begin{array}{l}\text { Foxcroft, D.R., and Tsertsvadze, A. (2011), "Universal school-based } \\
\text { prevention programs for alcohol misuse in young people", Cochrane } \\
\text { Database of Systematic Reviews Issue 5. Art. No.: CD009113. DOI: } \\
\text { 10.1002/14651858.CD009113. }\end{array}$ \\
\hline Alcohol & $\begin{array}{l}\text { Wood, E.F., Shakeshaft, A.P., Gilmour, S., Sanson-Fisher, R.W. } \\
\text { (2006), "A systematic review of school-based studies involving } \\
\text { alcohol and the community", Australian and New Zealand Journal of } \\
\text { Public Health, Vol. } 30 \text { No.6, pp. 541-549 }\end{array}$ \\
\hline Diet & $\begin{array}{l}\text { Delagado-Noguera, M., Tort, S., Martinez-Zapata, M.J., Bonfill, X. } \\
\text { (2011), "Primary school interventions to promote fruit and vegetable } \\
\text { consumption: A systematic review and meta-analysis", Preventive } \\
\text { Medicine Vol. } 53 \text { No. 1, pp. 3-9 }\end{array}$ \\
\hline Diet & $\begin{array}{l}\text { de Sa, J., and Lock, K. (2008), "Will European agricultural policy for } \\
\text { school fruit and vegetables improve public health? A review of school } \\
\text { fruit and vegetable programmes", European Journal of Public Health } \\
\text { Vol. } 18 \text { No.6, pp. 558-568 }\end{array}$ \\
\hline $\begin{array}{l}\text { Emotional } \\
\text { and social } \\
\text { wellbeing }\end{array}$ & $\begin{array}{l}\text { Blank, L., Baxter, S., Goyder, L., Guillaume, L., Wilkinson, A., } \\
\text { Hummel, S., Chilcott, J. (2009), "Systematic review of the } \\
\text { effectiveness of universal interventions which aim to promote } \\
\text { emotional and social wellbeing in secondary schools". School of } \\
\text { Health and Related Research (ScHARR), Sheffield. }\end{array}$ \\
\hline $\begin{array}{l}\text { Violence } \\
\text { prevention }\end{array}$ & $\begin{array}{l}\text { Mytton, J.A., DiGuiseppi, C., Gough, D., Taylor, R.S., Logan, S. } \\
\text { (2006), "School-based secondary prevention programmes for } \\
\text { preventing violence". Cochrane Database of Systematic Reviews, } \\
\text { Issue 3. Art. No.: CD004606. DOI: } \\
\text { 10.1002/14651858.CD004606.pub2. }\end{array}$ \\
\hline $\begin{array}{l}\text { Health } \\
\text { promotion } \\
\text { (general) }\end{array}$ & $\begin{array}{l}\text { Joronen, K., Rankin, S.H., Astedt-Kurki, P. (2008), "School-based } \\
\text { drama interventions in health promotion for children and adolescents: } \\
\text { systematic review" Journal of Advanced Nursing Vol. } 63 \text { No. 2, pp. } \\
116-131\end{array}$ \\
\hline $\begin{array}{l}\text { Health } \\
\text { promotion } \\
\text { (general) }\end{array}$ & $\begin{array}{l}\text { Wainwright, P., Thomas, J., Jones, M. (2000), "Health promotion and } \\
\text { the role of the school nurse: a systematic review" Journal of } \\
\text { Advanced Nursing Vol. } 32 \text { No.5, pp. 1083-1091 }\end{array}$ \\
\hline $\begin{array}{l}\text { Mental } \\
\text { Health }\end{array}$ & $\begin{array}{l}\text { Kavanagh, J., Oliver, S., Lorenc, T., Caird, J., Tucker, H., Hardenm } \\
\text { A., Greaves, A., Thomas, J., Oakley, A. (2009), "School-based } \\
\text { cognitive-behavioural interventions : A systematic review of effects } \\
\text { and inequalities". Health Sociology Review Vol. } 18 \text { No. 1, pp. } 61-78\end{array}$ \\
\hline $\begin{array}{l}\text { Mental } \\
\text { Health }\end{array}$ & $\begin{array}{l}\text { Schachter, H.M., Girardi, A., Ly, M., Lacroix, D., Lumb, A.B., van } \\
\text { Berkom, J., Gill, R. (2008), "Effects of school-based interventions on } \\
\text { mental health stigmatization: a systematic review" Child and } \\
\text { Adolescent Psychiatry and Mental Health Vol. } 2 \text { No. } 18\end{array}$ \\
\hline Nutrition & $\begin{array}{l}\text { Kristjansson, B., Petticrew, M., MacDonald, B., Krasevec, J., Janzen, } \\
\text { L., Greenhalgh, T., Wells, G.A., MacGowan, J., Farmer, A.P., Shea, }\end{array}$ \\
\hline
\end{tabular}




\begin{tabular}{|c|c|}
\hline & $\begin{array}{l}\text { B., Mayhew, A., Tugwell, P.,Welch, V. "School feeding for } \\
\text { improving the physical and psychosocial health of disadvantaged } \\
\text { students" (2007), Cochrane Database of Systematic Reviews, Issue } 1 . \\
\text { Art. No.: CD004676. DOI: 10.1002/14651858.CD004676.pub2. }\end{array}$ \\
\hline Nutrition & $\begin{array}{l}\text { van Cauwenberghe, E., Maes, L., Spittaels, H., van Lenthe, F.J., } \\
\text { Brug, J., Oppert, J.M., de Bourdeaudhuij, I. (2010) "Effectiveness of } \\
\text { school-based interventions in Europe to promote healthy nutrition in } \\
\text { children and adolescents: systematic review of published and 'grey' } \\
\text { literature". British Journal of Nutrition Vol. } 103 \text { No. 6, pp. 781-797 }\end{array}$ \\
\hline $\begin{array}{l}\text { Obesity/ } \\
\text { overweight }\end{array}$ & $\begin{array}{l}\text { Jaime, P.C., and Lock, K. (2009), "Do school based food and } \\
\text { nutrition policies improve diet and reduce obesity?" Preventive } \\
\text { Medicine Vol. } 48 \text { No. 1, pp. } 45-53\end{array}$ \\
\hline $\begin{array}{l}\text { Obesity/ } \\
\text { overweight }\end{array}$ & $\begin{array}{l}\text { Stevens, C.J. (2010). "Obesity Prevention Interventions for Middle } \\
\text { School-Age Children of Ethnic Minority: A Review of the } \\
\text { Literature". Journal for Specialists in Pediatric Nursing Vol. } 15 \text { No. } \\
\text { 3, pp. 233-243 }\end{array}$ \\
\hline $\begin{array}{l}\text { Physical } \\
\text { activity }\end{array}$ & $\begin{array}{l}\text { Dobbins, M., Husson, H., DeCorby, K., LaRocca, R.L. (2009), } \\
\text { "School-based physical activity programs for promoting physical } \\
\text { activity and fitness in children and adolescents aged } 6 \text { to } 18 \text { ". } \\
\text { Cochrane Database of Systematic Reviews Art. No.: CD007651. } \\
\text { DOI:10.1002/14651858.CD007651.pub2. }\end{array}$ \\
\hline $\begin{array}{l}\text { Physical } \\
\text { activity }\end{array}$ & $\begin{array}{l}\text { Kriemler, S., Meyer, U., Martin, E., van Sluijs, E.M., Andersen, L.B., } \\
\text { Martin, B.W. (2011) "Effect of school-based interventions on } \\
\text { physical activity and fitness in children and adolescents: a review of } \\
\text { reviews and systematic update". British Journal of Sports Medicine } \\
\text { Vol. } 45 \text { No. 11, pp. 923-930 }\end{array}$ \\
\hline $\begin{array}{l}\text { Physical } \\
\text { health (other) }\end{array}$ & $\begin{array}{l}\text { D’Onise, K., Lynch, J.W., Sawyer, M.G., McDermott, R.A. (2010), } \\
\text { "Can preschool improve child health outcomes? A systematic } \\
\text { review”. Social Science \& Medicine Vol. } 70 \text { No. 9, pp. 1923-1940 }\end{array}$ \\
\hline $\begin{array}{l}\text { Physical } \\
\text { health (other) }\end{array}$ & $\begin{array}{l}\text { Steele, E.J., Dawson, A.P., Hiller, J.E. (2006), “School-Based } \\
\text { Interventions for Spinal Pain: A Systematic Review”. Spine Vol. } 31 \\
\text { No. 2, pp. 226-233 }\end{array}$ \\
\hline Sexual abuse & $\begin{array}{l}\text { Topping, K.J., and Barron, I.G. (2009), "School-Based Child Sexual } \\
\text { Abuse Prevention Programs: A Review of Effectiveness". Review of } \\
\text { Educational Research Vol. } 79 \text { No. 1, pp. 431-463 }\end{array}$ \\
\hline Sexual abuse & $\begin{array}{l}\text { Zwi, K., Woolfenden, S., Wheeler, D.M., O’Brien, T., Tait, P., } \\
\text { Williams, K.J. (2007), "School-based education programmes for the } \\
\text { prevention of child sexual abuse”. Cochrane Database of Systematic } \\
\text { Reviews Issue 3. Art. No.: CD004380. DOI: } \\
\text { 10.1002/14651858.CD004380.pub2. }\end{array}$ \\
\hline Sexual health & $\begin{array}{l}\text { Blank, L., Baxter, S.K., Payne, N., Guillaume, L.R., Pilgrim, H. } \\
\text { (2010), "Systematic review and narrative synthesis of the } \\
\text { effectiveness of contraceptive service interventions for young people, } \\
\text { delivered in educational settings". Journal of Pediatric \& Adolescent } \\
\text { Gynecology Vol. } 23 \text { No. 6, pp. 341-351 }\end{array}$ \\
\hline Sexual health & $\begin{array}{l}\text { Owen, J., Carroll, C., Cooke, J., Formby, E., Hayter, M., Hirst, J. } \\
(2010) \text {, "School-linked sexual health services for young people }\end{array}$ \\
\hline
\end{tabular}




\begin{tabular}{|l|l|}
\hline & $\begin{array}{l}\text { (SSHYP): a survey and systematic review concerning current models, } \\
\text { effectiveness, cost-effectiveness and research opportunities". Health } \\
\text { Technology Assessment Vol. 14 No. 30. }\end{array}$ \\
\hline Smoking & $\begin{array}{l}\text { Thomas, R.E., and Perera, R. (2006), "School-based programmes for } \\
\text { preventing smoking". Cochrane Database of Systematic Reviews } \\
\text { Issue 3. Art. No.: CD001293. DOI: } \\
\text { 10.1002/14651858.CD001293.pub2. }\end{array}$ \\
\hline Smoking & $\begin{array}{l}\text { Uthman, O., Yahaya, I., Pennant, M., Bayliss, S., Aveyard, P., Jit, M., } \\
\text { Barton, P., Meads, C., Chen, Y-F. (2009), School-based Interventions } \\
\text { to Prevent the Uptake of Smoking Among Children and Young } \\
\text { People: Effectiveness Review. West Midlands Health Technology } \\
\text { Assessment Collaboration, University of Birmingham, Birmingham. } \\
\text { [pdf Downloadable from NICE website at: } \\
\text { http://www.nice.org.uk/Guidance/PH23/Evidence] accessed 20 } \\
\text { December 2012 }\end{array}$ \\
\hline $\begin{array}{l}\text { Substance } \\
\text { abuse }\end{array}$ & $\begin{array}{l}\text { Faggiano, F., Vigna-Taglianti, F.D., Versino, E,, Zambon, A., } \\
\text { Borracino, A., Lemma, P. (2008) "School-based prevention for illicit } \\
\text { drugs use: a systematic review". Preventive Medicine Vol. 46 No. 5, } \\
\text { pp. 385-396 }\end{array}$ \\
\hline $\begin{array}{l}\text { Substance } \\
\text { abuse }\end{array}$ & $\begin{array}{l}\text { Lemstra, M., Bennett, N., Nannapaneni, U., Neudorf, C., Warren, L., } \\
\text { Kershaw, T., Scott, C. (2010) "A systematic review of school-based } \\
\text { marijuana and alcohol prevention programs targeting adolescents } \\
\text { aged 10-15". Addiction Research \& Theory Vol. 18 No. 1, pp. 84-96 }\end{array}$ \\
\hline $\begin{array}{l}\text { Miscellan- } \\
\text { eous }\end{array}$ & $\begin{array}{l}\text { Duperrex, O., Blackhall, K., Burri, M., Jeannot, E. (2009), "Education } \\
\text { of children and adolescents for the prevention of dog bite injuries". } \\
\text { Cochrane Database of Systematic Reviews Issue 2. Art. No.: } \\
\text { CD004726. DOI: 10.1002/14651858.CD004726.pub2. }\end{array}$ \\
\hline
\end{tabular}

